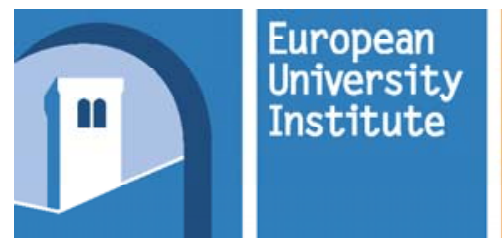

Co-financed by the European Union

\title{
India-EU Migration: the Social Security Rights of Indian Nationals Moving to and within the European Union
}

\section{A.P. van der Mei}

CARIM-India Research Report 2013/24

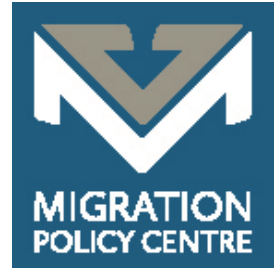

\section{Maastricht University}

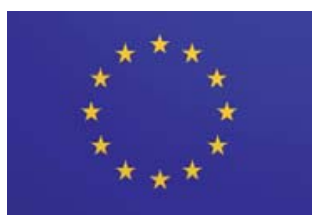


CARIM-India

Developing a knowledge base for policymaking on India-EU migration

Research Report

Thematic Report

CARIM-India RR2013/24

\section{India-EU Migration: the Social Security Rights of Indian Nationals Moving to and within the European Union}

A.P. van der Mei

Associate Professor in EU law, Maastricht Center for European Law (MCEL) 
This text may be downloaded only for personal research purposes. Any additional reproduction for other purposes, whether in hard copies or electronically, requires the consent of the Robert Schuman Centre for Advanced Studies.

Requests should be addressed to India-EU.Migration@eui.eu

If cited or quoted, reference should be made as follows:

A.P. van der Mei, India-EU Migration: the Social Security Rights of Indian Nationals Moving to and within the European Union, CARIM-India RR 2013/24, Robert Schuman Centre for Advanced Studies, San Domenico di Fiesole (FI): European University Institute, 2013.

THE VIEWS EXPRESSED IN THIS PUBLICATION CANNOT IN ANY CIRCUMSTANCES BE REGARDED AS THE OFFICIAL POSITION OF THE EUROPEAN UNION

\author{
European University Institute \\ Badia Fiesolana \\ I - 50014 San Domenico di Fiesole (FI) \\ Italy \\ http://www.eui.eu/RSCAS/Publications/ \\ http://www.india-eu-migration.eu/publications/ \\ http://cadmus.eui.eu
}




\section{CARIM-India - Developing a knowledge base for policymaking on India-EU migration}

This project is co-financed by the European Union and carried out by the EUI in partnership with the Indian Council of Overseas Employment, (ICOE), the Indian Institute of Management Bangalore Association, (IIMB), and Maastricht University (Faculty of Law).

The proposed action is aimed at consolidating a constructive dialogue between the EU and India on migration covering all migration-related aspects. The objectives of the proposed action are aimed at:

- Assembling high-level Indian-EU expertise in major disciplines that deal with migration (demography, economics, law, sociology and politics) with a view to building up migration studies in India. This is an inherently international exercise in which experts will use standardised concepts and instruments that allow for aggregation and comparison. These experts will belong to all major disciplines that deal with migration, ranging from demography to law and from economics to sociology and political science.

- Providing the Government of India as well as the European Union, its Member States, the academia and civil society, with:

1. Reliable, updated and comparative information on migration

2. In-depth analyses on India-EU highly-skilled and circular migration, but also on low-skilled and irregular migration.

- Making research serve action by connecting experts with both policy-makers and the wider public through respectively policy-oriented research, training courses, and outreach programmes.

These three objectives will be pursued with a view to developing a knowledge base addressed to policy-makers and migration stakeholders in both the EU and India.

Results of the above activities are made available for public consultation through the website of the project: http://www.india-eu-migration.eu/

For more information:

CARIM-India

Robert Schuman Centre for Advanced Studies (EUI)

Convento

Via delle Fontanelle 19

50014 San Domenico di Fiesole

Italy

Tel: +39055 4685817

Fax: + 390554685770

Email: India-EU.Migration@eui.eu

\section{Robert Schuman Centre for Advanced Studies}

http://www.eui.eu/RSCAS/ 


\section{Table of Contents}

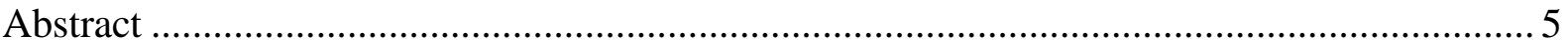

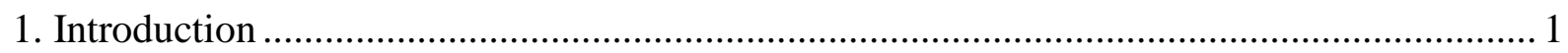

2. Indian Workers Moving between EU Member States: The EU's Internal Coordination

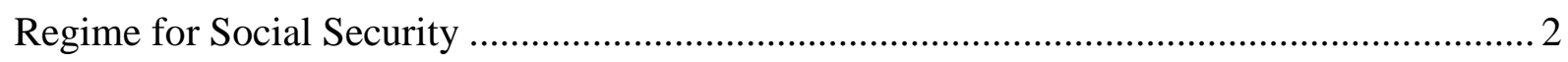

2.1 Application of Coordination Regime to Third Country Nationals ................................. 2

2.2 Rules Determining the Applicable Legislation .............................................................. 3

2.2.1 General Rules Applicable to ‘Ordinary’ Workers.................................................. 4

2.2.2 Special Rules Applicable to Posted Workers .............................................................. 5

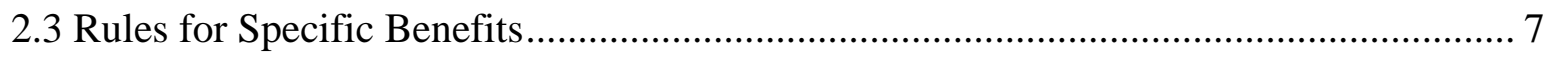

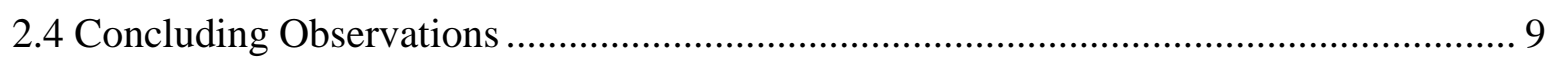

3. Indian Nationals Moving to EU Member States ............................................................. 9

3.1 Equal Treatment for Indian Nationals in the Field of Social Security .......................... 10

3.1.1 European Convention on Human Rights............................................................... 10

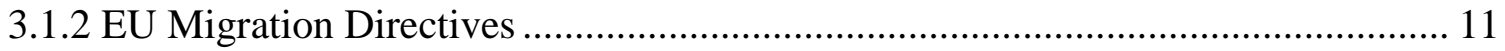

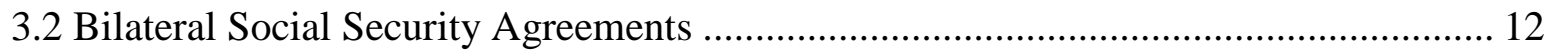

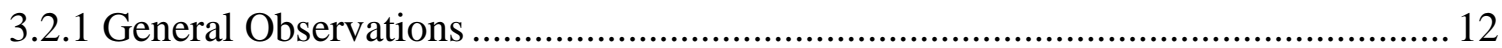

3.2.2 The Social Security Agreements Concluded between India and Belgium and the

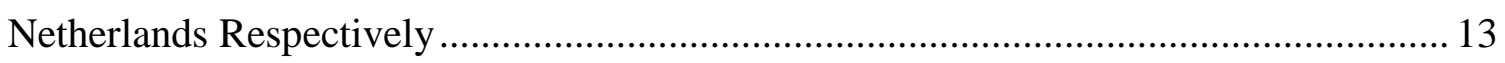

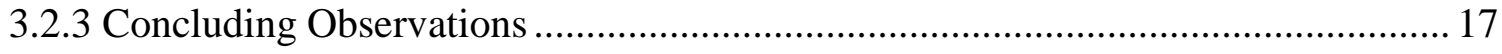




\begin{abstract}
With the intensification of the economic relationships between India and the European Union (EU) labour mobility from India to the EU is bound to increase in the forthcoming years. This mobility raises numerous questions not only as regards immigration and labour market access, but also in relation to social social security. This paper focuses on the social security status of Indian nationals moving to EU Member States for employment reasons. It presents and analyses, first, the EU's internal social security coordination regime with a view to establishing the social security status of third country nationals, and Indian workers in particular, moving between EU Member States and, second, the external coordination applicable to Indian nationals, moving from India to individual EU Member States (Belgium and the Netherlands) for employment reasons.
\end{abstract}




\section{Introduction}

With the intensification of the economic relationships between India and the European Union (EU) labour mobility from India to the EU is bound to increase in the forthcoming years. Indian companies are likely to post more and more workers to EU Member States, whereas European companies will be keen to increasingly hire technically qualified Indian workers especially in sectors like information technology, engineering, health, finance and management. ${ }^{1}$

The foreseen increase in labour flows raises numerous questions not only as regards immigration and labour market access, but also in relation to taxation and social social security. This paper focuses on the social security status of Indian nationals moving to EU Member States for employment reasons. ${ }^{2}$ The goal is not to provide a comprehensive, in-depth overview and analysis of social security status of Indian nationals working in EU Member States. This is virtually, if not entirely, impossible. Ultimately, the answer to the question of whether, when and what social security contributions Indian workers (or their employers) will have to pay and what benefits they may be entitled to ultimately depends (i) on national law and rules, which vary from EU Member State to EU Member State and are constantly subject to changes in each one of them, and (ii) the countless different specific situations Indian workers may find themselves in. The goal of this paper is rather to present and analyse the main European and international law social security norms applicable to third country workers, and Indian workers in particular, moving to and within the EU. It concerns rules that determine the (EU Member) State in which workers are insured and principles of cross-border social security law such as nondiscrimination on grounds of nationality, portability of benefits and aggregation of insurance, employment or residence periods that national social security institutions will have to observe when applying their national rules.

The paper first discusses the social security rights of Indian nationals moving between EU Member States and, subsequently, the status of Indian nationals moving between India and individual EU Member States. As such, from a chronological migration perspective, this does not seem to be the most logical order, as Indian nationals will first have to move to a specific EU Member State before they can move to another. The reason for the indicated order of discussion concerns the nature and scope of cross-border social security regimes. As regards the movement of persons between EU Member States the EU legislator has developed a comprehensive 'internal' regime linking national social security systems to the benefit of intra-EU migrants and travellers, including both EU citizens and third country nationals, that is governed in essence by two EU regulations. The 'external' coordination regime applicable to the third country nationals moving to an EU Member State is far less developed and less transparent than the 'internal' coordination regime. It is 'patchy' framework governed by a multiplicity of legal instruments, including EU (migration) directives, multilateral (human rights) treaties and bilateral social security agreements (SSAs) concluded between third countries and individual EU Member States. For most Indian nationals this 'external' coordination regime is most relevant, but to achieve a proper understanding of it and its limitations, it is useful to commence with a description of the more mature 'internal' coordination regime.

\footnotetext{
${ }^{1}$ Press Information Bureau, Government of India, 'India Poised for Social Security Agreements with Several Countries Indian Workers Abroad to Get Better Deal’, 17 September 2008, available on: http://pib.nic.in/newsite/erelease.aspx?relid=42874.

${ }^{2}$ Some attention will be paid too to the social security rights of Indian nationals who after a short-term or long-term stay in the EU return to India, and the possibility to export 'European' benefits in particular. This paper does not address the legal status in the field of social security of (i) Indian nationals establishing themselves as self-employed persons in EU Member States, (ii) economically inactive Indians moving to EU Member States and (iii) EU nationals moving to India.
} 


\section{Indian Workers Moving between EU Member States: The EU's Internal Coordination Regime for Social Security}

\subsection{Application of Coordination Regime to Third Country Nationals}

The EU's internal coordination regime for social security has been created to facilitate the exercise of the right to freedom of movement that the Treaty on the Functioning of the European Union (TFEU) ${ }^{3}$ confers upon EU citizens. ${ }^{4}$ The regime is governed by Regulations $883 / 2004^{5}$ and 987/2009, ${ }^{6}$ which seek to link the national social security systems in such a way that movement from one Member State to another does not, or as little as possible, lead to a loss of social security rights. ${ }^{7}$ Regulation 883/2004 (the 'basic Regulation'8) contains the substantive rights and duties; Regulation 987/2009 ('implementing Regulation'9) provides detailed rules for the administration cooperation between national social security institutions necessary for the implementation of the rights and duties set out in the basic Regulation.

Even though third country nationals do not in principle enjoy internal freedom of movement within the Union, the EU legislator has decided that they should enjoy similar social security protection when they move from one Member State to another. Regulation $1231 / 10^{10}$ has extended the aforementioned two Regulations to third country nationals. ${ }^{11}$

In order to benefit from the internal coordination regime third country nationals have to satisfy several conditions. First, they must be legally resident in the territory of a Member State. Lawful residence may derive from EU law (e.g. the the Blue Card Directive, ${ }^{12}$ the Third-country Researcher Directive ${ }^{13}$ or the Long Term Residence directive ${ }^{14}$ ), international treaties and/or national immigration law.

\footnotetext{
${ }^{3}$ See in particular Arts 20 (Union citizenship), 21 (freedom of movement for EU citizens) and 45 (free movement of workers).

${ }^{4}$ For an overview see F Pennings, European Social Security Law, $5^{\text {th }}$ ed. (Antwerp - Intersentia - 2010).

${ }^{5}$ Regulation (EC) No 883/2004 of the European Parliament and of the Council of 29 April 2004 on the coordination of social security systems (OJ 2004 L 166, p. 1). This Regulation has replaced as of 1 May 2010 Regulation No 1408/71 on the application of social security schemes to employed persons, to self-employed persons and to members of their families moving within the Community (OJ, English Special Edition 1971 (II), p. 416), as amended and updated by Council Regulation (EC) No 118/97 of 2 December 1996 (OJ 1997 L 28, p. 1), as amended by Regulation (EC) No 592/2008 of the European Parliament and of the Council of 17 June 2008 (OJ 2008 L 177, p. 1).

${ }^{6}$ Regulation (EC) No 987/2009 of the European Parliament and of the Council of 16 September 2009 laying down the procedure for implementing Regulation (EC) No 883/2004 (OJ 2009 L 284, p. 1). This Regulation has replaced Regulation (EEC) No
} 574/72 laying down the procedure for implementing Regulation (EEC) No 1408/71 (OJ 1997 L 28 p. 1).

${ }^{7}$ The Regulations also apply to Iceland, Norway and Liechtenstein and Switzerland.

${ }^{8}$ Art.1(1)(a) Reg.987/2009.

${ }^{9}$ Art.1(1)(b) Reg.987/2009.

${ }^{10}$ Regulation (EU) No 1231/2010 of the European Parliament and of the Council of 24 November 2010 extending Regulation (EC) No 883/2004 and Regulation (EC) No 987/2009 to nationals of third countries who are not already covered by these Regulations solely on the ground of their nationality (OJ 2010, L 344, 1). The original social security Regulations 1408/71 and 574/72 had already been extended to third country nationals by Council Regulation (EC) No 859/2003 of 14 May 2003 extending the provisions of Regulation (EEC) No 1408/71 and Regulation (EEC) No 574/72 to nationals of third countries who are not already covered by those provisions solely on the ground of their nationality (OJ 2003, L 124).

${ }^{11}$ On the application of the internal social security coordination regime to third country nationals see e.g. D Pieters and P Schoukens (eds), The Social Security Co-ordination between the EU and Non-EU Countries (Antwerp - Intersentia 2009); K Eisele, The External Dimension of the EU's Migration Policy - Different Legal Positions of Third-Country Nationals in the EU A Comparative Perspective (Oisterwijk - Wolf Legal Publishers - 2013), Part VI and Commission of the European Communities et al, Social Security in Europe - Equality between Nationals and Non-Nationals (1995).

${ }^{12}$ Council Directive 2009/50/EC of 25 May 2009 on the conditions of entry and residence of third-country nationals for the purposes of highly qualified employment (OJ 2009, L 155). 
Second, third country nationals must be or have been subject to the legislation of a Member State. As a rule, Indian nationals working in an EU Member State will satisfy this condition, but the same does not always hold true, for instance, for Indian nationals who have been posted by an Indian employer to an EU Member State. On the basis of bilateral social security agreements that India has concluded with some EU Member States (see Section 3) Indian posted workers may remain subject to Indian social security legislation. They are not insured in an EU Member State and, hence, cannot benefit from Regulation 1231/10 juncto Regulation 883/2004 if they are subsequently posted to another Member State. ${ }^{15}$

Third, third country nationals must find themselves in a situation "which is not confined in all respects within a single Member State”. This so-called "internal situation rule" or phrased reversely, the requirement of a cross-border element, is an expression of the basic rule underlying the internal coordination regime that it only builds bridges between national social security systems but leaves the internal organisation and features of the systems untouched. The rule implies that an Indian national working and living in Germany cannot rely on Regulation 1231/10 juncto Regulation 883/2004 to challenge German social security rules. However he may do so when, for example, he also works or his family members live in another Member State. Generally, Indian nationals who live in a single EU Member State, have never crossed the borders between the member States and have no other ties with another Member State can only benefit from the rules discussed in Section 3 of this paper.

\subsection{Rules Determining the Applicable Legislation}

Regulation 883/2004 contains various principles, which each serve the common goal of ensuring that persons who move from one EU Member State to another are not penalized in the field of social security. The leading principles include:

- equal treatment regardless of nationality: ${ }^{16}$ EU Member States must treat nationals of other EU Member States or third countries equally as their own nationals - nationals rules or acts that either directly or indirectly favour their own nationals over non-nationals are, absent justification, prohibited;

- aggregation of insurance periods: ${ }^{17}$ if the legislation of a EU Member State makes the acquisition, retention, duration or recovery of the right to benefits conditional upon the completion of periods of insurance, employment, self-employment or residence, periods completed in other Member States must be taken into account;

- portability of benefits: ${ }^{18}$ cash benefits shall not be subject to any reduction, amendment, suspension, withdrawal or confiscation in case the beneficiary resides in the territory of another Member State. ${ }^{19}$

(Contd.)

13 Council Directive 2005/72/EC of 12 October 2005 on a specific procedure for admitting third-country nationals for the purposes of scientific research (OJ 2005, L 289).

${ }^{14}$ Council Directive 2003/109 of 25 November 2003 concerning the status of third-country nationals who are long-term residents (OJ 2004, L 16).

${ }^{15}$ It is not necessarily required that a worker performs activities on the territory of a Member State. The internal social security regime is applicable as long as the employment relationship has a sufficiently close link with the Union. Case C60/93 Aldewereld [1994] ECR I-2991. For example, an Indian worker who is sent to perform activities outside the Union may be insured if his employer is based in an EU Member State.

16 Art.4 Reg.883/2004.

${ }^{17}$ Art.6 Reg.883/2004. Mention may further be made of the principle of the assimilation of benefits, incomes, facts or events according to which, in brief, facts or events that are of legal relevance to the social security status of a person and have occurred in another Member State must be considered to have occurred in the State of insurance. Art.5 Reg.883/2004.

18 Art.7 Reg.883/2004. 
The hard core of the internal coordination regime, however, consists of the rules determining the applicable legislation. Before the above-mentioned principles can be applied, it is first necessary to establish where a worker is insured. In principle, the right to benefit from aggregation rules or to export benefits only exists in the Member State of insurance, the so-called competent State. ${ }^{20}$

\subsubsection{General Rules Applicable to 'Ordinary’ Workers}

The main goal of these rules is to avoid situations in which persons finding themselves in a crossborder situation are insured in more than one EU member State or in none. Hence, the leading principle is that persons shall be subject to the legislation of a single Member State only (the so-called single State rule). ${ }^{21}$ In essence, the rules determining the applicable rules seek to settle positive and negative conflicts of law which would arise if it were for national law alone. For example, for a given social security risk Member State A has chosen employment on national territory as the criterion for mandatory statutory insurance. For the same risk neighbouring Member State B has chosen a residence based scheme. A (n Indian) national working in Member State A and living in Member State B would, on the basis of the national laws of Member States A and B, be insured in both Member States. He could be required to pay double premiums and possibly receive double benefits. In the reverse situation, id est if the worker concerned would be living in EU Member State A and be working in EU Member State B, he would be insured in neither one of the two States. To effectuate the single State rule, the rules determining the applicable indicate which of the two EU Member States must be regarded as the competent one and which, to the exclusion of the other 'non-competent' State, must apply its legislation to the worker. ${ }^{22}$

For economically active persons, the so-called lex loci laboris applies: employed and selfemployed persons are subject to the legislation of the Member States where they perform their activities. ${ }^{23}$ Thus, in the above example, if the (Indian) worker is employed in EU Member State A and lives in EU Member State B, the former is the competent State. It is in that State that the (Indian) worker (or his employer) can be required to pay social security contributions and, if he satisfy the applicable eligibility requirements, may claim benefits. IN principle, no such duties and rights exist in the Member State B.

The lex loci laboris does not always ensure that workers are subject to the legislation of one Member State only. The reason is simple: they may pursue economic activities in more than one EU member State. In order to ensure that workers are subject to the legislation of one EU Member State only, Regulation 883/2004 provides for specific choice of law rules for various situations. ${ }^{24}$

\section{(Contd.)}

${ }^{19}$ Mention is further made of the rule on the prevention of overlap to benefits: beneficiaries cannot derive from Regulation $883 / 2004$ the right to several benefits of the same kind for one and the same period of compulsory insurance. Art.10 Reg.883/2004.

${ }^{20}$ Art.1(s) Reg.883/2004.

21 Art.11(1) Reg.883/2004.

${ }^{22}$ In situations of positive conflicts of law, the rules produce so-called exclusive effect, which implies that the competent Member State must apply its legislation and prohibits the non-competent one to do so (even though according to its own rules the person concerned would be insured). Case 302/84 Ten Holder [1986] ECR 1821. More recently, the Court seems to have adopted a more 'flexible' approach to the notion of exclusive effect. Case C-352/06 Bosmann [2008] ECR I-3827 and Joined Cases C-611/10 and C-612/10 Hudziński and Wawrzyniak [2012] ECR I-0000. In situations of negative conflicts of law the competent Member State must apply its legislation to the person concerned (even though according to its own rules the person concerned would not be covered by the insurance scheme). Case 276/81 Kuijpers [1982] ECR 3027.

${ }^{23}$ Persons who are not economically active are subject to the legislation of their Member State of residence. Art.11 (1) (e).

${ }^{24}$ Comparable rules exist for self-employed persons. Art.13(2) Reg.883/2004. Persons who are employed in one Member State and self-employed in another are subject to the legislation in the Member State of employment. Art.13(3) Reg.883/2004. 
- Persons who work for one employer in different Member States. Such workers are subject to the legislation of the Member State of residence if they pursue a substantial part (id est in principle a minimum of $25 \%)^{25}$ of their activity there. If they do not do so, they are covered by the legislation of the Member State where the employer is registered or established. ${ }^{26}$ For example, an Indian worker lives in Member State A. He works two days a week in Member State A and 3 days in Member State B. The worker is insured in Member State A. If, however, the worker only works one day a week in the State of residence (for example from home), he is insured in the Member State B.

- Persons employed by various employers or undertakings who are established or registered in different Member States. Such workers are insured in the Member State where they reside if they pursue a substantial part of their activity there. ${ }^{27}$ Again, if they do not do so, they are subject to the social security system of the Member State where the employer is registered or established. ${ }^{28}$ For example, an Indian worker who works 2 days a week for a company in Member State A and three days for another company in Member State B and who lives in Member State A, is insured in the latter Member State.

- Persons who work in two or more Member States for an employer established outside the territory of the EU. Such workers are subject to the legislation of the EU Member State on whose territory they reside. ${ }^{29}$ For example, an Indian worker lives in Member State A and is employed by a company based in New Delhi. He works both in Member State A and in Member State B. The worker is insured in Member State A, even if his activities cannot be regarded as 'substantial'.

\subsubsection{Special Rules Applicable to Posted Workers}

Regulation 883/2004 contains an important exception to the lex loci laboris rule for employees who have been sent by their employer to perform activities in another Member State, the so-called posted workers. Article 12(1) provides:

'A person who pursues an activity as an employed person in a Member State on behalf of an employer which normally carries out its activities there and who is posted by that employer to another Member State to perform work on that employer's behalf shall continue to be subject to the legislation of the first Member State, provided that the anticipated duration of such work does not exceed twenty-four months and that he is not sent to replace another person. ${ }^{30}$

The rationale behind the exception for posted workers is twofold. ${ }^{31}$ First, application of the lex loci laboris would imply that each time a worker is posted to another Member State the legislation of another Member State would apply. This would lead to administrative complications which could

\footnotetext{
25 To determine whether a substantial part of the activities is pursued in a Member State, the following indicative criteria are taken into account: (a) in the case of an employed activity, the working time and/orthe remuneration; and (b) in the case of a self-employed activity, the turnover, working time, number of services rendered and/or income. A share of less than $25 \%$ in respect of these criteria constitutes an indication that a substantial part of the activities is not being pursued in the relevant Member State. Art.14(7) Reg.987/2009.

${ }^{26}$ Art.13(1) Reg. 883/2004.

${ }^{27}$ Ibid.

${ }^{28}$ Ibid.

${ }^{29}$ Art.14(11) Reg.987/2009.

${ }^{30}$ A comparable exception exists for self-employed persons. Art.12(2) of Reg. 883/2004.

31 See first recital of Decision No A2 of 12 June 2009 of the Administrative Commission for the Coordination of Social Security Systems concerning the interpretation of Article 12 of Regulation (EC) No 883/2004 of the European Parliament and of the Council on the legislation applicable to posted workers and self-employed workers temporarily working outside the competent State (OJ 2010, C 106).
} 
obstruct the employer's right to pursue economic activities on a temporary basis in another Member States. Second, if it were not for the exception, posted workers (or their employers) would be obliged to pay premiums in the Member State where the activities are performed. In many instances, however, these contributions do not lead to entitlement to benefits because of the (too) short duration of the activities. By stipulating that posted workers remain subject to the legislation of the Member State from which they are sent Article 12(1) thus facilitates freedom of movement and serves the interests of both posted workers and posting employers.

To benefit from Article 12(1) several conditions must be met. ${ }^{32}$ First, the employer must normally carry out his activities in the State in which he is established (the 'posting State'). ${ }^{33}$ Second, there must be, throughout the period of posting, a direct relationship between the posting employer and the posted worker. ${ }^{34}$

The possibility to rely on Article 12(1) is limited in two respects. First, the length of the period during which the posted worker shall remain covered by the legislation is maximized to 24 months. ${ }^{35}$ The reason for this limitation is, first, to protect the interests of the Member State where the posted activities are performed (as this Member State is not permitted in particular to levy premiums) and, second, to avoid 'social dumping' which could occur if employers establish themselves in Member States where premiums are relatively low and subsequently post workers to other States. ${ }^{36}$ Second, Article 12 cannot be relied upon for by or for workers who are sent to replace another posted worker.

To rely on Article 12 some formalities must be fulfilled. In brief, ${ }^{37}$ the employer that posts a worker to another Member State must contact the competent social security institution in the posting State in advance. The employee shall be provided with a portable document or certificate ('A 1') by the competent institution in the posting State, which certifies that the worker qualifies to be a posted worker up to a certain date and thus remains subject to the legislation of that Member State. ${ }^{38}$

${ }^{32}$ Posted workers may include persons who are recruited with a view to being posted to another Member State, provided that, immediately before the start of his employment, the person concerned is already subject to the legislation of the Member State in which his employer is established. Art.14(1) Reg.987/2009.

${ }^{33}$ This implies that the employer ordinarily performs substantial activities, other than purely internal management, activities, in the territory of the Member State in which it is established, taking account of all criteria characterising the activities carried out by the undertaking in question (Art.14(2) Reg.987/2009), including the place where the employer has its registered office, the number of administrative staff present in the posting State and the State where the activities are performed, the place where the posted workers have been recruited, the law applicable to the contracts and the turnover achieved in each of the two States involved (Decision No A2 (n31), point 1 and European Commission, Practical Guide The Legislation that Applies to Workers in the European Union (EU), the European Economic Area (EEA) and Switzerland, Social Europe, 2011, p.7).

34 In order to establish whether such a direct relationship continues to exist, assuming therefore that the worker continues to be under the authority of the employer which posted him, a number of elements have to be taken into account, including responsibility for recruitment, employment contract, remuneration (without prejudice to possible agreements between the employer in the sending State and the undertaking in the State of employment on the payment to the workers), dismissal, and the authority to determine the nature of the work. Decision No A2 (n 31), point 1.

${ }^{35}$ The competent authorities of the State of employment and the sending State may agree, however, to extend this 24 month period by concluding an agreement to this effect. Art.16 Reg.883/2004.

${ }^{36}$ For those reasons it is stipulated that once a worker has ended a period of posting, no fresh period of posting for the same worker, the same undertakings and the same Member State can be authorised until at least two months have elapsed from the date of expiry of the previous posting period. See Decision No A2 of 12 June 2009 (n 31), point 3c.

${ }^{37}$ For further details see European Commission, Practical Guide (n 33).

38 The institution in the State of employment is bound by this certificate, but it may express doubts about the correctness stated therein. Case C-202/97 Fitzwilliam [2000] ECR I-883. Possible disputes between the institutions of the two Member States are resolved by the rules and procedures set out in Decision No A1 of the Administrative Commission for the Coordination of Social Security Systems of 12 June 2009 concerning the establishment of a dialogue and conciliation procedure concerning the validity of documents, the determination of the applicable legislation and the provision of benefits under Regulation (EC) No 883/2004 of the European Parliament and of the Council (OJ 2010, C 106). 


\subsection{Rules for Specific Benefits}

Once it is established that Indian workers fall within the scope of the 'internal coordination' regime as governed by Regulation 1231/10 juncto Regulation 883/2004, they can be required to pay social security contributions on the basis of the legislation of the competent State and enjoy the rights Regulation 883/2004 offers in the social security fields to which it applies. The Regulation applies to and contains special rules for sickness benefits, maternity and equivalent paternity benefits, invalidity benefits, old-age benefits, survivors' benefits, benefits in respect of accidents at work and occupational diseases, death grants, unemployment benefits, pre-retirement benefits, family benefits and special non-contributory benefits. ${ }^{39}$ Social assistance and special benefits for victims of war are explicitly excluded $^{40}$ and Regulation 883/2004 does not contain rules on student financial aid.

The rights most relevant for Indian workers can be briefly summarized as follows:

- Health Care. Indian workers who are living in the State in which they are insured are entitled to healthcare (including medicines) in accordance with the legislation of that Member State. In addition, they can rely on Regulation 883/2004 to obtain, at the expense of the organ they are insured with, medical care in other Member States.

o This includes first of all access to healthcare in the State of their residence (if this is another one than the competent State) ${ }^{41}$ and the State of employment (if they live outside that Member State). ${ }^{42}$

o In addition, Indian workers who travel for work or other reasons to other Member States are entitled to the care that becomes necessary during their visit or stay. ${ }^{43}$ This right to so-called 'unplanned care' is supported by the European Health Insurance Card (EHIC).

o Finally, as all other beneficiaries of the coordination regime for healthcare, Indian workers may travel to other Member States for the sole purpose of obtaining medical care. For hospital care in particular, however, the competent State may make reimbursement of such 'planned care' conditional upon prior authorisation. ${ }^{44}$ This authorisation must in principle be granted if the treatment needed is (i) included in the 'insurance package' of the State concerned and (ii) cannot be provided there within a medically justifiable time limit. ${ }^{45}$

- Sickness Benefits. These benefits, id est benefits that replace a wage that has been suspended due to sickness, as well as maternity and paternity benefits are in all circumstances paid according to the rules of the Member State where workers are insured, regardless of the Member States in whose territory they are living or staying. ${ }^{46}$

\footnotetext{
${ }^{39}$ Art.3 Reg.883/2004. For further info and details see Pennings (n4).

${ }^{40}$ Art.3(5) Reg.883/2004.

${ }^{41}$ Art.17 Reg.883/2004. This also holds true for family members.

42 Art.18 Reg.883/2004. In principle, this also holds true for family but Member States have the option of denying them access to healthcare in the competent State by indicating this in an Annex to Reg.883/2004.

43 Art.19(1) Reg.883/2004.

${ }^{44}$ Art.20(1) reg.883/2004. See further Arts 7-9 of Directive 2011/24/EU of the European Parliament and of the Council of 9 March 2011 on the application of patients' rights in cross-border healthcare (OJ 2011, L 88). See further A P van der Mei, 'De Nieuwe Richtlijn betreffende de Toepassing van de Rechten van Patiënten bij Grensoverschrijdende Zorg', Nederlands Juristenblad, 2011, 2712-2719 and F Pennings, 'The Cross-Border Health Care Directive: More Free Movement for Citizens and More Coherent EU Law?’, 13 European Journal of Social Security, 2011, 424-452.

45 Art.20(3) Reg.883/2004 and Art.8 of o Directive 2011/24/EU (n41).

${ }^{46}$ Art.21 Reg.883/2004.
} 
- Benefits in the Event of Accidents at Work. In essence the rules here are similar to the ones applicable to health care and sickness benefits. ${ }^{47}$

- Pensions. When workers reach the pension age in the competent State they are entitled to pension there, provided they have been insured for old age for at least one year. ${ }^{48}$ Those who have worked, and have been insured, in more than one Member State receive separate old age pensions from the respective Member States. The pensions are calculated according to the workers' insurance record in each country. ${ }^{49}$ The sum to be received corresponds to the length of insurance. Old age pensions are payable regardless of the Member State where the retired worker may live. ${ }^{50}$ The rules applicable to invalidity pensions ${ }^{51}$ and to pensions for surviving spouses or orphans are in essence similar to those applicable to old-age pensions.

- Unemployment Benefits. The basic starting-point is that workers are, in event of loss of employment, entitled to unemployment benefits in the competent State. There is one major exception: wholly unemployed frontier workers ${ }^{52}$ are subject to the unemployment benefit laws in the State of their residence. Thus, an Indian frontier worker living in Member State A and working in Member State B is entitled to unemployment benefit in Member State A if he becomes wholly unemployed. However, if he becomes partially unemployed, ${ }^{53}$ the worker should turn to Member State B for a benefit. In establishing entitlement to such benefits, the competent institutions must take into consideration periods of insurance or employment completed in other Member State. ${ }^{54}$ Unemployed persons who wish to look for a new job in another Member State can export their unemployment benefit for a period of three months, which may be extended up to six months. ${ }^{55}$

- Family Benefits. If children live in the competent State where the worker is insured, this Member State is responsible for payment of family benefits in accordance with its national legislation. Workers are also entitled to benefits for children living in another Member State. ${ }^{56}$ In case both parents work in different Member States, special priority rules exist to prevent double entitlement to family benefits. ${ }^{57}$ If the benefits received in the Member State that has been given 'priority' are lower than in the other Member State, in the latter a right to a supplement exist. For example, an Indian worker works in Member State A and his spouse in Member State B. Both spouses are in principle entitled to family benefits for their children regardless of where these live. The priority rules indicate that Member State A is responsible for payment of family benefits. If the family benefits in Member State B are higher, the spouse working in that Member State B may claim a supplement in that State covering the difference in the amounts involved. Thus, if both Member States offer 100 Euro for a child, the worker gets 100 Euro from Member State A and nothing from Member State B. However, if the amount in Member State B would be 200 Euro, the worker will receive 100 in Member State and, as a supplement, also 100 from Member State B.

\footnotetext{
${ }^{47}$ Arts 36-41 of Reg.883/2004.

${ }^{48}$ Only statutory pensions are covered to the exclusion in principle of supplementary or contractual pensions. See Art.3 juncto Art.1(l) Reg.883/2004.

${ }^{49}$ Arts 50-60 Reg.883/2004.

${ }^{50}$ Art.7 Reg.883/2004.

51 Arts 44-49 Reg.883/2004.

52 A frontier worker is a person pursuing an activity as an employed person in a Member State and who resides in another Member State to which he returns as a rule daily or at least once a week are returned there daily, or at least once a week. Art.1(f) Reg.883/2004.

${ }^{53}$ On the distinction between wholly unemployed and partially unemployed see Case C-444/98 de Laat [2001] ECR I-2229.

${ }^{54}$ Art.61 Reg.883/2004.

${ }^{55}$ Art.64 Reg.883/2004. See Joined cases 41/79, 121/79 and 796/79 Testa [1980] ECR 1979.

${ }^{56}$ Art.67 Reg.883/2004.

${ }^{57}$ Art.68 Reg.883/2004.
} 


\subsection{Concluding Observations}

All in all, Regulations 883/2004 and 987/2009 provide for a quite comprehensive coordination regime that links the Member States' social security systems in such a way that individuals, including both EU citizens and third country nationals, who move from one Member State to another are not faced with a loss of social security rights. To be sure, the 'internal' coordination regime does not ensure that cross-border movement is 'neutral" ${ }^{58}$ in the sense that it may never have negative financial consequences. For example, an Indian worker who first works in a Member State that offers comparatively high social security benefits and then takes up employment in a less 'generous' Member State may be faced with lower benefits or, in case he does not satisfy the criteria for entitlement to benefit, no benefit at all. Cross-border movement may lead to a decrease in 'social security income'. What the coordination regime guarantees is that workers are subject to the legislation of one Member State and that that legislation is applied with due respect for the principles of non-discrimination, aggregation and portability. Ultimately, the answer to the question of whether or not a person is insured, can be required to pay contributions and claim certain benefits is to be determined on the basis of national law, which, as noted before, varies enormously from Member State to Member State and from time to time. The system builds bridges between national social security systems, but does not affect the systems as such.

As complicated as the system may be, it works quite well and this can be partly attributed to the fact that the coordination system is supported by a close administrative cooperation between the social security institutions of the Member States that is based on mutual trust and cooperation. ${ }^{59}$ Regulation 987/2009 contains detailed rules imposing on national institutions specific obligations concerning cooperation, exchange of data and other formalities for each of branche of social security. It is these practical, administrative rules that transform the rights contained in Regulation 883/2004 into a practical reality for the beneficiaries of the internal coordination regime.

\section{Indian Nationals Moving to EU Member States}

The legal picture as regards the social security status of Indian nationals moving from India to individual EU Member States differs fundamentally from those moving within the EU. No single comprehensive regime coordinating the national social security systems of EU Member States and those of third countries, including the Indian one, exists. As stated earlier, the external coordination regime is 'patchy', ${ }^{60}$ governed as it is by a multiple legal instruments including multilateral (human rights) treaties, EU (migration) directives and bilateral social security agreements.

In essence, however, the external regime can be said to rest on two pillars. First, third country nationals are offered equality of treatment with host State nationals in social security matters. Second, bilateral social security agreements (SSAs) offer additional protection by providing rules determining the legislation to be applied, aggregation of insurance or employment periods and/or portability rules, especially for pensions. These principles are basically the same as the ones on which the 'internal' coordination regime is based, but they do not offer similar protection to workers moving from a third country like India to an EU Member State. India has concluded bilateral agreements with only some EU Member States and these agreements are limited in scope and do not provide for a full-fletched coordination regime comparable to the one set in place by Regulations 883/2004 and 987/2009.

\footnotetext{
${ }^{58}$ Case C-208/07 von Chamier-Glisczinski [2009] ECR I-6095.

${ }^{59}$ See Art.4(3) TEU and e.g. Decision No A1 of the Administrative Commission (n 38).

${ }^{60} \mathrm{COM}(2012) 153$ final, at p.2.
} 


\subsection{Equal Treatment for Indian Nationals in the Field of Social Security}

As stated, the first pillar of the external coordination regime consists of a right to equal treatment for third country nationals, and Indian nationals in particular, with the nationals of the host EU Member State. This right is guaranteed by various instruments. Most relevant for present purposes are the European Convention on Human Rights (ECHR) and EU migration directives.

\subsubsection{European Convention on Human Rights}

Article 14 ECHR, which provides that the enjoyment of rights set forth in the Convention shall be secured without discrimination on any ground including national origin, read in conjunction with Article 1 of Protocol No 1 to the ECHR, which offers a right to the peaceful enjoyment of possessions, has been interpreted by the European Court of Human Rights (ECtHR) to imply equality of treatment in the field of social security ${ }^{61}$ State parties to the ECHR are under no obligation to create social benefit schemes, but if they decide to do so, they generate a proprietary interest falling within the ambit of Protocol No. 1 and are bound to observe the non-discrimination rule contained Article 14 ECHR. ${ }^{62}$ This right is ensured regardless of nationality, and thus extends to nationals of third countries, including India.

The above does not imply that States cannot make any difference in treatment: only a differential treatment of similar situations is prohibited and such differential treatment may be permissible when it serves an objective and legitimate aim. ${ }^{63}$ The ECtHR has left States a certain margin of appreciation in assessing possible justifications. Application of Article 14 ECHR, as a rule, implies that distinctions between nationals and non-nationals are prohibited, but the same does not necessarily hold true for national rules requiring residence on national territory.

For example, in the recent judgment in EFE v. Austria the ECtHR concluded that an Austrian rule reserving a certain type of family benefits to persons ${ }^{64}$ whose children are living in Austria did not violate Article 14 ECHR. $^{65}$ It observed that Austria intended to establish certain minimum standards of living for all children living in Austria. As a measure forming part of Austria's population policy, family allowances were granted with the aim of sharing the burden between families as an investment in future generations in the context of the 'intergenerational contract' to which children living outside the country are unlikely to contribute in the future. The ECtHR concluded that the Austrian social security system was primarily designed to cater for the needs of the resident population and that persons whose children live outside Austria cannot be said to be in a relevantly similar position to persons whose children do live there. Generally speaking, it seems fair to conclude that the prohibition of discrimination on nationality grounds demands a de-nationalization but not a de-territorialisation of social security schemes.

${ }^{61}$ Gaygusuz v. Austria, 16 September 1996, \& 42, Reports 1996-IV and Stec and Others v. the United Kingdom, GC, nos.65731/01 and 65900/01, \& 53, ECHR 2006-VI. The ECtHR has not always been consistent, but it would seem that most social security benefits, be they contributory or non-contributory (Koua Poirrez v. France, 30 September 2003, no.40892/98), can be regarded as falling within the ambit of Art.1 of Protocol no.1 to the ECHR, thus triggering for the State concerned the duty to equal treatment. See S G Nägel and F R Kessler, Social Security Law, Council of Europe (Wolters Kluwer - Austin - 2010), 39-47.

${ }^{62}$ Carson and Others v. the United Kingdom, GC, no.42184/05, ECHR 2010.

${ }^{63}$ Burden v. the United Kingdom, GC, no.13378/05, \& 60, ECHR 2008.

${ }^{64}$ On the compatability of residence requirement for family benefits for parents themselves see e.g. judgments of 25 October 2005, Niedzwiecki v. Germany, no, 58453/00 and Okpisz v. Germany, no.59140/00.

${ }^{65}$ EFE v. Austria, no.9134/06, Judgment of 8 January 2013. See further Carson and others v. the United Kingdom, GC, no.42184/05, ECHR 2010 and A McColgan, 'Cracking the Comparator Problem: Equal Treatment and the Role of Comparisons’, European Human Rights Review 11 (2006) 650-677. 


\subsubsection{EU Migration Directives}

Equality of treatment in the field of social security is further guaranteed by EU migration Directives. The Directives for highly qualified workers ${ }^{66}$ and researchers ${ }^{67}$ basically do so in relation to all branches of social security covered by Regulation 883/2004. The 'Single Permit' ${ }^{\text {' }}$ does the same, but allows Member States to restrict equal treatment in relation third-country workers who are not or have not been in employment for a minimum period of six months. ${ }^{69}$ In addition, Member States may decide that family benefits shall not apply to third-country nationals who have been authorised to work in the territory of a Member State for a period not exceeding six months, to third-country nationals who have been admitted for the purpose of study, or to third-country nationals who are allowed to work on the basis of a visa. ${ }^{70}$ The Single Permit Directive specifically adds that beneficiaries who move to a third country must be treated equally as host State nationals as regards rules on the portability of old age, invalidity and death, statutory pensions. ${ }^{71}$

The Long-term Residents Directive ${ }^{72}$ offers beneficiaries equal treatment with host State nationals as regards study grants ${ }^{73}$ and 'social security, social assistance and social protection as defined by national law' ${ }^{74}$ As regards the latter two, however, Member States may limit equal treatment to 'core benefits' ${ }^{75}$ In Kamberaj the Court of Justice gave important clarification to this right to equal treatment. In answering the question whether housing benefits are covered by the Directivet, the Court stated that the reference 'as defined by national law' does not mean that Member States are wholly free to fill in the terms social security, social assistance and social protection. Member States must take into consideration the objective of the Long-Term Residence Directive to promote the integration of long-term residents into the host state, as well as Article 34(3) of the EU Fundamental Rights Charter, which states that the Union (and thus its Member States) recognises and respects 'the right to social and housing assistance so as to ensure a decent existence for all those who lack sufficient resources, in accordance with the rules laid down by European Union law and national laws and practices.' Further, as regards the power of the Member States to limit equal treatment to 'core benefits', the Court held that this power does not allow them to exclude from equal treatment 'minimum income support, assistance in the case of illness, pregnancy, parental assistance, and longterm care' and benefits, which enable individuals to meet their basic needs such as food, health and accommodation, including the housing benefit under consideration.

\footnotetext{
${ }^{66}$ Art. 14 (1)(e) Dir. 2009/50 (n 12).

${ }^{67}$ Art. 12 (c) Dir. 2005/71 (n13).

68 Art.12(1) Directive 2011/98/EU of the European Parliament and the Council of 13 December 2011 on a single application procedure for a single permit for third-country nationals to reside and work in the territory of a Member State and on a common set of rights for third-country workers legally residing in a Member State (OJ 2011, L 343).

${ }^{69}$ Art.12(2)(b) Dir.2011/98.

${ }^{70}$ Ibid.

${ }^{71}$ Art.12(4) Dir.2011/98.

72 Art.11 (1)(d) Dir.2003/109/EC. See also A Farahat, 'Is there a Human Right to Equal Social Security? EU Migration Law and the Requirements of Art. 9 ICESCR', in: M Maes, M -C Foblets and Ph De Bruycker (eds.), External Dimensions of European Migration and Asylum Law and Policy (Bruylant, Bruxelles, 2011), 529-548.

${ }^{73}$ Art.11(1)(b) Dir.2003/109.

${ }^{74}$ Case C-571/10 Kamberaj [2012] ECR I-0000, as discussed in A P van der Mei, 'Overview of Recent cases Before the European Court of Human Rights and the European Court of Justice (April-June 2012), 14 European Journal of Social Security (2012) 199-211).

75 Art.11(4) Dir.2003/109.
} 
The EU migration directives reflect the basic notion that the longer a third country national has resided in an EU Member States, the broader the scope of their right to equal treatment in social security matters reaches. ${ }^{76}$

\subsection{Bilateral Social Security Agreements}

\subsubsection{General Observations}

As relevant as equal treatment may be, it does not suffice for adequately protecting the social security rights of migrants. In particular, it does not eliminate problems of double or non-insurance and obstacles to portability of benefits or aggregation of insurance periods. To better protect migrants' social security rights, and more generally to facilitate migration and trade with partner States, ${ }^{77}$ States often, and increasingly, conclude SSAs. ${ }^{78}$ They do so, however, on an ad hoc basis. ${ }^{79}$ They conclude social security agreements with some but not with other States and both the scope and the substance differs from treaty to treaty, everything being dependent on the interests of the countries involved, the type of benefit schemes that exist in the countries concerned, the number of people moving between the countries, etc.

The substantive scope may differ ranging from agreements that cover virtually all social security risks or regimes to agreements only covering certain of these risks. ${ }^{80}$ Usually, however, old-age pensions are included and are made exportable. Social assistance and student financial aid, however, are as a rule not captured by SSAs. As to the personal scope of the agreements a distinction can be made between 'closed' agreements, which are only applicable to nationals of the contracting State parties, and 'open' or 'universally applicable' agreements that extend to all persons insured under national law, regardless of nationality. ${ }^{81} \mathrm{~A}$ key aspect of virtually all SSAs concerns the rules determining the applicable legislation. Some are based on the principle of integration, which links social security rights and duties to the State of residence, whilst others are based on the principle insurance which connect persons for insurance to the State of employment. ${ }^{82}$ Quite common are exception to the latter principle for posted workers.

\footnotetext{
${ }^{76}$ Eisele (n 11) 175.

77 The EU also has concluded agreements covering social security issues with third countries, including 3urkey and the Maghreb countries. See further Eisele (n11) part VI and H Verschueren, 'Social Security Coordination in the Agreements between the EU and the Mediterranean Countries, in particular Turkeu and the Maghreb Countries, in: Pieters/Schoukens (n 13), 1955. No such social security agreement has been arranged with India.

${ }^{78}$ Such bilateral social security agreements are considered good practice and are promoted by inter alia the International Labour Organisation and the Council of Europe through non-binding social security model provisions. See further J Nickless and H Siedl, Coordination of Social Security in the Council of Euope: Short Guide (Council of Europe Publishing - 2004). Agreements concluded between EU Member States are in principle replaced by Regulation 883/2004, even though certain provisions of 'old' agreements may still apply under certain condition. Art.8 Reg. 883/2004.

${ }^{79}$ The European Commission has called for a more coordinated approach, but so far no such strategy has been developed. $\operatorname{COM}(2012) 153$ final.

${ }^{80}$ G Strban, 'The Existing Bilateral and Multilevel Social Security Instruments Binding EU States and Non-EU-States', in D Pieters and P Schoukens (eds), The Social Security Co-Ordination between the EU and non-EU Countries (Intersentia Antwerp - 2009) 85-113, 89.

${ }^{81}$ When EU Member States apply SSAs concluded with a non-EU Member State they must respect EU law, and the prohibition of nationality discrimination in particular. More concretely, when Member States grant their own nationals a given advantage (e.g. aggregation of insurance periods) on the basis of a bilateral treaty concluded with a third non-EU State, they must award the same advantage to nationals of other Member States finding themselves in a similar situation. Case C-55/00 Gottardo [2002] ECR I-413. Because of Gottardo, SSAs concluded by EU member States with third countries are nowadays open agreements.

${ }^{82}$ Strban (n80) 92-93.
} 
To facilitate migration and posting of workers to Europe, India has concluded SSAs with several EU Member States, including Belgium (2009), the Czech Republic (2010), Denmark (2010), France (2008), Germany (2008 and 2011), Hungary (2010), Luxembourg (2009) and the Netherlands (2009) ${ }^{83}$ To illustrate the impact of these SSAs, this Section takes a closer look at two of these agreements: the India-Belgium ${ }^{84}$ and the India-Netherlands SSAs. ${ }^{85}$ The two agreements are based on reciprocity and cover both the social security rights and duties of Indian nationals in the respective two EU Member States as well as the rights and duties of persons moving to India. As stated earlier in the Introduction, the discussion below focusses only on the social security status of Indian nationals moving for employment reasons to EU Member States.

\subsubsection{The Social Security Agreements Concluded between India and Belgium and the Netherlands Respectively}

The two SSAs are structured comparably and include provisions on the personal scope, legislative scope, equal treatment, portability, the applicable legislation, administrative cooperation, enforcement and entry into force. The India-Belgium SSA, however, is more extensive in that it contains provisions detailing entitlement to certain specific benefits.

\section{A. Scope}

As to the personal scope both constitute SSAs 'open' agreements: they do not only cover nationals of the contracting States but all persons who are or have been subject to the legislation of either one of the two States, as well as persons -read family members- who derive rights from such persons. ${ }^{86}$

The legislative or substantive scope covers listed social security benefit risks/schemes. More concretely, the India-Belgium SSAs offers (Indian) workers who have moved to Belgium equal treatment as regards (i) old-age and survivors' pension for employed persons and self-employed persons, (ii) invalidity insurance for employed persons, sailors of the merchant marine and selfemployed persons and, for the purposes of the rules determining the applicable legislation (see below under C), (iii) social security for employed persons. ${ }^{87}$

${ }^{83}$ For text and further details see http://www.india-eu-migration.eu/database/legal-module/?search=1\&country=socagr.

84 Agreement between the Kingdom of Belgium and the Republic of India on social security. Belgian Law Gazette, 21 August 2009. The agreement was signed on 3 day of November 2006, entered into force 1 September 2009 and has been concluded without any limitation on its duration (art.27). See also the Administrative Arrangement concerning Implementation of the Agreement between the Kingdom of Belgium and the Republic of India. Belgian Law Gazette, 31 August 2009

85 Agreement on Social Security between the Republic of India and the Kingdom of the Netherlands, Tractatenblad, 2009, 213. The agreement was signed on 22 October 2009, entered into force on 1 December 2011 and has been concluded for an unlimited period of time (Art.22). See also the Administrative Agreement for the implementation of the Agreement on Social Security between the Kingdom of the Netherlands and the Republic of India, Tractatenblad, $2009,213$.

86 Art.3 SSA India-Belgium and Art.3 SSA India-Netherlands. Thus, not only Indian nationals but also other persons who move from India to Belgium c.q. the Netherlands and are or have been covered by Indian legislation can rely on the SSA's provisions in Belgium c.q. the Netherlands.

87 Art.2(1)(a) India-Belgium SSA. Unlike the India-Netherlands SSA, the India-Belgium SSA specifically states that it shall apply to legislation which will amend or extend legislation specified in Art.2(1) and, in principle, to legislation which will extend the existing schemes to new categories of beneficiaries. However, the India-Belgium SSA does not in principle apply to legislations that establish a new social security branch. Art.2(2) India-Belgium SSA. In addition, and again unlike the India-Netherlands SSA, the India-Belgium SSA contains a specific provision on 'Reduction or Suspension Clauses', according to which the reduction or suspension clauses provided for in the legislation of one Contracting State, in case one benefit coincides with other social security benefits or with other professional incomes, shall be applied to the beneficiaries, even if these benefits were acquired by virtue of a scheme of the other Contracting State, or if the related professional activities are exercised in the territory of the other Contracting State. Art.6 India-Belgium SSA. 
Comparably, the India-Netherlands SSA applies to Dutch legislation on social insurance concerning (i) old age, (ii) disablement, (iii) survivors, and for the purposes of the rules determining the applicable legislation (see below under $\mathrm{C}$ ), (iv) sickness (including the scheme concerning the liability of the employer and benefit in kind), (v) maternity, (vi) unemployment and (vii) children's allowances.

\section{B. Export of Benefits}

Both SSAs provide for equality of treatment with nationals of the host State when they 'ordinarily reside' in that State's territory. ${ }^{88}$ In addition, they both stipulate that 'a Contracting State shall not reduce or modify benefits acquired under its legislation solely on the ground that the beneficiary stays or resides in the territory of the other Contracting State. ${ }^{89}$ The scope of the equal treatment and portability provisions, however, is limited. They only apply to old-age, survivors and invalidity insurance/disablement benefits. The Belgian social security benefits for employed persons, and the Netherlands sickness, maternity, unemployment and children's benefits are, as stated above under A only captured by the SSAs for the purposes of the rules determining the applicable legislation. As regards equal treatment this does not seem to be truly relevant as Indian nationals will be entitled to claim such treatment under the instruments discussed in Section 3.2.1 and/or national law. However, the above does imply that portability of benefits to India is limited to old-age, survivors and invalidity insurance/disablement benefits ${ }^{90}$ to the exclusion of the Belgian social security benefits for employed persons, and the Netherlands sickness, maternity, unemployment and children's benefits.

As regards the Netherlands, the SSA specifically excludes two types of benefits from portability. ${ }^{91}$ This concerns, first, benefits awarded on the basis of the Supplementary Benefits Act (Toeslagenwet), which supplement other social security benefits up to the minimum subsistence standard in the Netherlands in case these other social benefits fall below that standard and, second, benefits offered under the Disablement Assistance Act for Handicapped Young Persons (Wet Werk en Arbeidsondersteuning Jonggehandicapten - Wajong) that specifically meant for you persons who are due to physical or mental reasons unable to perform work of economic value.

\section{Rules Determining the Applicable Legislation}

The hard core of the two SSAs consists of rules determining the applicable legislation, which seek to prevent double social security coverage and to avoid non-coverage for persons moving between or working in the territories of the Contracting parties. The starting point is, as under the EU's 'internal' coordination regime, the lex loci laboris: persons who work as an employee in the territory of a Contracting State shall be subject to only the legislation of that Contracting State. ${ }^{92}$ Thus, Indian

${ }^{88}$ Art.4 SSA India-Belgium and Art.4 SSA India-Netherlands.

${ }^{89}$ Art.5(1) SSA India-Belgium and Art.5(1) SSA India-Netherlands. Viewed from the perspective of Dutch legislation, the conclusion of SSAs is a prerequisite for portability of benefits. Since 1 January 2000, the day the Act Restriction Export of Benefits (Wet Beperking Export Uitkeringen - BEU) entered into force, the right to social security benefits is, in principle, linked to residence in the Netherlands. Portability of benefits is made conditional upon agreements with other States, which should contain rules guaranteeing the lawfulness of benefits and payments thereof. Such agreements may be 'supranational' in nature (e.g. Regulation 883/2004) or be concluded on a bilateral basis with other States (e.g. India).

90 These benefits can be exported to India and to third countries, where and under the same conditions as Belgian respectively Dutch nationals are entitled to do so. Art.5(2) SSA India-Belgium and Art.5(3) SSA India-Netherlands. Further, as regards invalidity benefits, Art.15 of the India-Belgium SSA states that the competent Belgian authorities may make entitlement to such benefit of a beneficiary present in India conditional upon authorization, which can only be refused if the stay takes place in the period during which, by virtue of the Belgian legislation, the Belgian competent agency must estimate or revise the state of invalidity.

${ }^{91}$ Art.5(2) India-Netherlands SSA.

92 Art.7(a) SSA India-Belgium and Art.6(a) SSA India-Netherlands. Unlike the India- Belgium SSA, the India-Netherlands SSA extends the lex loci laboris to self-employed persons. The India-Netherlands SSA further indicates that this holds 
workers can only be required to pay social security contributions in Belgium respectively the Netherlands and are, in principle, exempt from that duty in India. Similarly, they can only receive benefits under Belgian respectively Dutch legislation.

The two SSAs contain specific rules concerning the applicable legislation for various categories of persons.

This first of all concerns persons working in the international transport sector. Persons who are member of the travelling or flying personnel of an enterprise which, operates international transport services for passengers or goods and has a registered office in the territory of a Contracting State, are subject to the legislation of the latter State. ${ }^{93}$ Thus, personnel of Indian airlines based in India but flying to the Zaventhem or Schiphol airports remain covered by the Indian legislation on social security.

The second category concerns seafarers. The India-Belgium SSA stipulates that a person who works on board of a ship that flies the flag of a Contracting State, shall be subject to the legislation of the State in which has his residence. ${ }^{94}$ The India-Netherlands SSA offers no concrete rule and holds that, as regards seafarers, cases of double coverage or non-coverage shall be resolved through consultations between the competent authorities of the Contracting States. ${ }^{95}$

A third category exempted from the lex loci laboris rule consist of civil servants, members of diplomatic missions and consular posts. They are subject not to the legislation of the host State but of the State for whose administration they perform their activities. ${ }^{96}$ Thus, the civil servants etc. working at the Indian embassy in Brussels or the Hague remain covered by the Indian social security rules. ${ }^{97}$

\section{Posted Workers}

The most important exception to the lex loci laboris rule, however, concerns posted workers. The India-Belgium SSA and the India-Netherlands SSA provide in identical terms:

'An employed person who, being in the service of an employer with an office on which he normally depends in the territory of one of the Contracting States and paying contributions under the legislation of that Contracting State, is posted by that employer in the territory of the other Contracting State to work on its account, shall remain subject to the legislation of the former Contracting State and continue to pay contributions under the legislation of this Contracting State, as if he continued to be employed in his territory on the condition that the foreseeable duration of his work does not exceed 60 months. ${ }^{98}$

Thus the workers ${ }^{99}$ of an Indian company who have been posted to Belgium or the Netherlands remain during the first five years subject to the Indian social security rules. They are under no duty to pay social security contributions and, the other side of the social security coin, cannot claim benefits under the host State's legislation. The same holds true for the family members that join them to the

(Contd.)

true for both employment based and residence based schemes. Article 10 expressly provides that a person who is subject to the legislation of once Contracting State shall be considered as residing in the territory of that State. Both SSAs provide for the possibility to grant exception on the application of the rules determining the applicable legislation in respect of particular persons or categories of persons. Art.10 India-Belgium SSA and Art.9 India-Netherlands SSA.

93 Art.7(b) SSA India-Belgium and Art.6(b) SSA India-Netherlands.

${ }^{94}$ Art.7(c) SSA India-Belgium.

${ }^{95}$ Art.6(c) SSA India-Netherlands.

${ }^{96}$ Art.9 India-Belgium SSA and Art. 8(1) India-Netherlands SSA. The same holds true for their family members, unless they exercise professional activities in the Netherlands. Art.9 India-Belgium SSA and Article 8(2) India-Netherlands SSA.

${ }^{97}$ If Indian nationals would also work in another Member State the special conflict rules described above (n 24 and accompanying text) as containe in Regulation 883/2004 apply.

${ }^{98}$ Art.8(1) SSA India-Belgium and Art.7(1) SSA India-Netherlands.

${ }^{99}$ No specific provision is made for posted self-employed persons, which would seem to imply that an Indian self-employed person based in India who posts himself or herself to the Netherlands is subject to Dutch legislation. 
Netherlands, unless the family members perform economic activities themselves. ${ }^{100}$ Once the 60 month period expires, the worker in question in principle is faced with a change in the State where he is insured: Indian legislation ceases to be applicable, Netherlands legislation becomes applicable.

The period during which posted workers remain exempt from the legislation of the State of employment is notably longer than under the EU's internal coordination regime: 60 months versus 24 months. As under Regulation 883/2004, the two SSAs under discussion allow the competent authorities of India and Belgium respectively the Netherlands to may agree that the worker in question remains subject to Indian legislation. ${ }^{101}$

The rule determining the applicable legislation for posted workers also applies in situations of subsequent posting. The two SSAs stipulate in identical terms that the 60 month rule extends to "a person who has been sent by his employer from the territory of one Contracting State to the territory of a third country and who remains subject to the legislation of first Contracting State, is subsequently sent by that employer from the territory of the third country to the territory of the other Contracting State.” This implies that an Indian worker who is first sent by his Indian employer to a third State (e.g. France), and thereupon posted to Belgium or the Netherlands, will remain covered by the Indian social security legislation for a maximum of in total 60 months.

The exemption of workers posted by Indian companies to Belgium c.q. the Netherlands from Belgium c.q. Dutch social security legislation is subject to the issuing by the competent Indian institution, the Employees' Provident Fund Organization (EPFO) of a certificate showing that the worker in question, and/or their family members, remain(s) subject to the Indian social security rules and liable there under for contribution. ${ }^{102}$ If this certificate is not issued, the Indian posted worker in principle is subject to Belgian respectively Dutch legislation, which implies in principle a possible duty to pay social security contributions.

\section{E. Aggregation}

In one respect the India-Belgium SSA is notably more extensive than the India-Netherlands SSA. That respect concerns old age, survivors and invalidity benefits. Under the former agreement these pensions or benefits are not only portable but they are also subject to aggregation rules. More specifically, for the acquisition, retention or recovery of the right to these benefits, the insurance periods completed pursuant to Indian legislation on these benefits are 'totalized', when necessary and to the extent they do not overlap, with the insurance periods completed pursuant to Belgian legislation. ${ }^{103}$ The Belgian authorities will make two calculations. First, they will calculate the old-age or survivor benefit under the Belgian schemes without 'totalisation' (or aggregation), id est on the basis of contributions paid in Belgium only. Second, they will calculate the (theoretical) amount of the benefit due as if all the insurance periods completed according to the two Contracting States' legislations were exclusively completed under the Belgian legislation, and then establish the amount due under Belgian legislation on a pro rate basis. Upon comparing the outcome of the two calculations, the Belgian authorities will pay the Indian national the higher of the two amounts. ${ }^{104}$

\footnotetext{
${ }^{100}$ Art.8(1) SSA India-Belgium and Art.7(1) SSA India-Netherlands.

${ }^{101}$ Art.8(2) India-Belgium SSA and Art.7(2) India-Netherlands SSA.

102 Art.4 Administrative Arrangement India-Belgium (n 84) and Art.3(1)(b) Administrative Agreement India-Netherlands (n 85).

103 Art.11(1) India-Belgium SSA.

104 Art.12 India-Belgium SSA.In case of a modification of the rules concerning old age, survivors', invalidity or disability benefits a re-calculation may have to be performed. There is no need for this if, because of the rising cost of living, the variation of the wage levels or other adaptation clauses, the benefits are changed with a given percentage or amount. Art.18 India-Belgium SSA.
} 


\section{F. Enforcement and Administrative Cooperation}

The two SSAs contain rules on the administrative cooperation between the Indian and the Belgian c.q. Dutch authorities needed for a proper implementation of the rights and duties set out in them, and these are worked out in further detail in Administrative Arrangements. ${ }^{105}$ The rules provide for mutual assistance, communication or exchange of any relevant information regarding entitlement or payment of benefits and changes in legislation, confidentiality of information about individuals, recognition of decisions and judgments and resolution of disputes between the contracting partners or their institutions. A notable difference between the two SSAs concerns the comparatively extensive attention given in the India-Netherlands SSA to issues concerning the correctness or legitimacy of payments of benefits. Thus, provisions are included on identification and proof of identity of applicants of benefits, ${ }^{106}$ verification of information regarding applicants or members of their family, ${ }^{107}$ medical examinations ${ }^{108}$ and adjustments of undue payments. ${ }^{109}$

\subsubsection{Concluding Observations}

The two SSAs' scope is quite limited and the protection offered falls short of the far more comprehensive EU's internal coordination regime for social security. Yet, as such the SSAs can be judged positively. They offer important clarification on the legislation to be applied to Indian workers who have taken up employment in, or have been posted by their Indian employers to, the respective Member States, they strengthen the notion that these workers should be treated equally as nationals of the host State and offer the possibility to export pension rights to India. The time that has passed since the entry into force of the two SSAs is too short to already be able to properly assess their added value and shortcomings, but there is no denying that they contribute to the goal of facilitating labour mobility between India and Belgium and the Netherlands respectively by offering protection that Indian workers do not enjoy on the basis of national law alone. Coordination of social security is, as the gradual development of and experiences with the EU's internal coordination regime demonstrate, largely a process of learning and adjusting to the development of migration flows and patterns as well as the never-ending changes in national social security systems. The SSAs reviewed in this paper will have to evaluated, perhaps adjusted or improved, but there is no denying that the three countries involved have set a good example for other States that seek to facilitate migration.

\footnotetext{
${ }^{105}$ See $n 84$ and n 85 respectively.

${ }^{106}$ Art.11 India-Netherlands SSA.

${ }^{107}$ Art.12 India-Netherlands SSA.

${ }^{108}$ Art.13 India-Netherlands SSA.

${ }^{109}$ Art.14 India-Netherlands SSA.
} 